Dokuz Eylül Üniversitesi-Mühendislik Fakültesi

Fen ve Mühendislik Dergisi

Cilt 19, Sayı 56, Mayıs 2017
Dokuz Eylul University-Faculty of Engineering Journal of Science and Engineering Volume 19, Issue 56, May 2017

\title{
Degradation of Triclosan by Photo-Fenton Oxidation
}

DOI: $10.21205 /$ deufmd.2017195654

\section{Ebru ÇOKAY*1, Merve ÖZTAMER ${ }^{1}$}

${ }^{1}$ Department of Environmental Engineering, Dokuz Eylul University, Buca,

\author{
35160, Izmir, Turkey
}

(Alınış / Received: 20.12.2016, Kabul / Accepted: 27.01.2017, Online Yayınlanma / Published Online: 02.05.2017)

Keywords

Box-Behnken

design,

Photo-Fenton

process,

Triclosan

\begin{abstract}
Triclosan is one of the most used active ingredients in antibacterial personal care products and its usage increased in recent years. Triclosan has recently attracted the attention researchers from the fields of water treatment due to its existence in water environments. This study has been executed to investigate the removal of triclosan with photo-Fenton process and to observe by-product formation after oxidation. Effects of operational parameters namely the concentrations of Triclosan, $\mathrm{H}_{2} \mathrm{O}_{2}$ and $\mathrm{Fe}(\mathrm{II})$ on oxidation of triclosan were investigated by using Box-Behnken statistical experiment design and the surface response analysis. It was found that the triclosan concentration has a more profound effect than $\mathrm{H}_{2} \mathrm{O}_{2}$ and $\mathrm{Fe}(\mathrm{II})$ concentrations for removal of triclosan in the aqueous solution. Complete removal of triclosan was accomplished within a hour, however, complete mineralization was not occurred even within sixty minutes indicating formation of some intermediate compounds such as 2,4-Dichlorophenol and 2,4,6-Trichlorophenol. Optimal $\mathrm{H}_{2} \mathrm{O}_{2} / \mathrm{Fe}(\mathrm{II}) / \mathrm{TCS}$ ratio resulting by maximum triclosan removal $(98.5 \%)$ was found to be $50 / 2 / 0.1$, respectively.
\end{abstract}

\section{Triklosanın Foto-Fenton Oksidasyon Yöntemi ile Parçalanması}

\begin{abstract}
Anahtar Kelimeler Özet: Triklosan, antibakteriyel kişisel bakım ürünlerinde en çok Box-Behnken kullanılan aktif maddelerden biridir ve son yıllarda kullanımı yöntemi, Foto-Fenton prosesi; Triklosan artmıştır. Bu çalışmada, triklosanın foto-Fenton yöntemi ile arıtılması ve yan ürünlerinin oluşumu araştırılmıştır. Triklosan, $\mathrm{H}_{2} \mathrm{O}_{2}$ ve $\mathrm{Fe}(\mathrm{II})$ konsantrasyonlarının triklosan giderimine olan etkileri, Box-Behnken istatistiksel deney tasarımı ve yüzey cevabı analizi kullanılarak araştırılmıştır. Triklosan derişiminin triklosan gideriminde $\mathrm{H}_{2} \mathrm{O}_{2}$ ve $\mathrm{Fe}(\mathrm{II})$ derişimlerinden daha etkin olduğu gözlenmiştir. Triklosan'ın tamamen parçalanması bir saatte gerçekleşirken tamamen mineralizasyonu gerçekleşmemiştir. 2,4Diklorofenol ve 2,4,6-Triklorofenol gibi bazı ara bileşiklerin oluştuğu gözlenmiştir. Foto-Fenton prosesinde, en yüksek triklosan giderimi (\%98.5) için $\mathrm{H}_{2} \mathrm{O}_{2} / \mathrm{Fe}(\mathrm{II}) / \mathrm{TCS}$ oranının $50 / 2 / 0.1$ olduğu saptanmıştır.
\end{abstract}




\section{Introduction}

Triclosan is one of the most used active ingredients in antibacterial personal care products and its usage increased in recent years. Also, triclosan have endocrine-disrupting properties. Because of its antimicrobial and antifungal properties, it is used an active ingredient in a variety of products where it acts to slow or stop the growth of bacteria, fungi, and mildew. According to EPA regulations, triclosan is used in commercial, institutional and industrial premises as a material preservative. Like every other chemical ingredients, triclosan is also released into the environment.

Triclosan is transported by means of domestic or industrial waste stream to wastewater treatment plants. Both incomplete removal of triclosan from wastewater treatment plants and spill out of spreading the triclosan laden sludge into soils, lead to triclosan spoils in soil and surface waters [1]. Therefore, triclosan has recently attracted the attentions of the researchers from water treatment field due to its existence in water environments as a result of widely usage in the world.

Triclosan, (2, 4, 4-trichloro-2-hydroxydi phenyl ether) (Figure 1) is a nonionic, a chlorinated aromatic compound broad spectrum antimicrobial chemical. Additionaly, it is a white powdered solid with a slight aromatic/phenolic odor and with low soluble in water (12 mg/L) [2]. Some physicochemical properties of triclosan are listed in Table 1 [2,3,4]. As can be seen in Table 1, triclosan has a highly hydrophobic nature with high log KOW value as 4.76 that it is likely to be absorbed in sediment. However, high amount of its usage, triclosan concentration increase in surface water and wastewater. Moreover, its half-life varies between 2 to 2000 days depending on the latitude and time of the year [5].<smiles>Oc1cc(Cl)ccc1Oc1ccc(Cl)cc1Cl</smiles>

Figure 1. Molecular structure of triclosan

Table 1. Physicochemical properties of triclosan

\begin{tabular}{ll}
\multicolumn{2}{l}{ Physicochemical Properties of Triclosan } \\
\hline Chemical formula & $\mathrm{C}_{12} \mathrm{H}_{7} \mathrm{Cl}_{3} \mathrm{O}_{2}$ \\
Molecular weight & $289.54 \mathrm{~g} / \mathrm{mole}$ \\
Appearance & White solid \\
Density & $1.49 \mathrm{~g} / \mathrm{cm}^{3}$ \\
Melting point & $55-57^{\circ} \mathrm{C}$ \\
Vapor pressure $\left(\right.$ at $\left.25^{\circ} \mathrm{C}\right)$ & $5.2 \times 10-6 \mathrm{~Pa}$ \\
Water solubility (at $\left.20^{\circ} \mathrm{C}\right)$ & $12 \mathrm{mg} / \mathrm{L}$ \\
Octanol-water partition & $4.8 \operatorname{log~KOW}$ \\
coefficient(at $\left.25^{\circ} \mathrm{C}\right)$ & $2-2000 \mathrm{~d}$ \\
\hline
\end{tabular}

Triclosan has been encountered in various type of water environment, such as surface waters, sediments and wastewater treatment plants' influent and effluents, at various concentrations $[6,7]$. For example, high levels were found in South China in the Pearl River system, where the triclosan concentration levels reached a maximum of $1.023 \mu \mathrm{g} / \mathrm{L}$ [8], and $478 \mu \mathrm{g} / \mathrm{L}$ [9].

In Europe, the presence of triclosan in surface water was investigated in some countries such as Italy, Switzerland, Greece, Spain, Romania etc. [10]. Triclosan was detected in Italian and Swiss lakes at concentrations up to 14 $\mu \mathrm{g} / \mathrm{L}$. In Switzerland, triclosan level was found in lakes and in a river with concentrations ranging from 1.4 to 74 $\mu \mathrm{g} / \mathrm{L}$ In the UK, triclosan level in a river ranged from 19 to $80 \mu \mathrm{g} / \mathrm{L}$. The highest values of triclosan were found as 285 $\mu \mathrm{g} / \mathrm{L}$ in rivers in Spain [11]. The highest concentrations of triclosan in river were 
quite recently reported in the Kaveri, Vellar, and Tamiraparani rivers in India, with values of $3800 \mu \mathrm{g} / \mathrm{L}, 5160$, and 944 $\mu \mathrm{g} / \mathrm{L}$, respectively [12].

Triclosan has been added into the draft specific pollutants' list prepared in accordance with Water Framework Directive (WFD-2000/60/EC). Triclosan is a spesific substances and it has annual avarage-environmental quality standart (AA-EQS) and maximum avarege concentation-environmental quality standart (MAC-EQS). These values are $0.12 \mathrm{ppb}$ and $1.1 \mathrm{ppb}$, respectively. According to this, monitoring studies should be done for the concentration of triclosan in surface waters consistently and necessary precautions and actions should also be taken. Some treatment technologies are recommended to for removal of triclosan in wastewater.

Generally, the removal efficiency of triclosan is depending on the initial triclosan concentration, $\mathrm{pH}$, matrix, and experimental conditions. Considering triclosan concentrations in wastewater treatment plant influents, some of byproducts are expected to be nonnegligible. Some of them show higher toxicity than triclosan. Eight by-products were identified after photodegradation of triclosan, including chlorinated phenols (2,4-dichlorophenol, 2,4,6trichlorophenol), 4-chlorocatechol and 4choloro-2,4-dihyroxydiphenyl ether 2,7and 2,8-dichlorodibenzo-p-dioxin, and a possible dichlorodibenzodioxin isomer or dichlorohydroxy-di-benzofuran $[13,14,15,16,17]$.

Recently, advanced oxidation processes (AOPs) were used as potential powerful methods that are capable of transforming the pollutants into harmless substances [18]. Almost all AOP's rely on the generation of reactive free radicals, such as hydroxyl, $\mathrm{OH} \bullet$ with a redox potential of $2.8 \mathrm{~V}$ [19]. The free radicals react rapidly with most of the organic compounds, either by addition to a double bond or by abstraction of a hydrogen atom from aliphatic organic molecules [20]. The resulting organic radicals then react with oxygen to initiate a series of oxidation reactions leading mineralization of the organics to produce $\mathrm{CO}_{2}$ and $\mathrm{H}_{2} \mathrm{O}$ [21]. Therefore, advanced oxidation is a promising alternative for mineralization and reducing recalcitrant organic compounds in water samples.

A limited number of studies were reported in the literature on photolysis of triclosan. However, the reported studies were mainly focused on the analysis and identification of the main products with proposals for the reaction mechanisms of photoreactions. Chlorinated by-products of triclosan may play an important role in the environmental impact of triclosan. As it has been reported that chlorination used during treatment produces chlorophenols which are more persistent and highly toxic compounds [22]. Due to these by-products that have not been analyzed and evaluated, the total concentration of triclosan and related byproducts in surface water or wastewater was underestimated. Based on these shortcomings, triclosan was selected as recalcitrant organic compound in order to observe triclosan removal and to evaluate by-products of triclosan in this study.

Advanced oxidation of triclosan containing aqueous solution by the Photo-Fenton oxidation was investigated in terms of triclosan and its byproducts removal. The effects of initial triclosan, $\mathrm{Fe}(\mathrm{II})$ and $\mathrm{H}_{2} \mathrm{O}_{2}$ concentrations on oxidation of triclosan were investigated by using a Box-Behnken statistical experiment design method. The main objective of the study was to statistically determine the most favorable levels of the parameters for the treatment of 
triclosan containing water samples and also to observe and to evaluate byproducts of triclosan.

\subsection{Design of experiments}

The classical approach of changing one variable at a time to study the effects of variables on the response is a complicated technique particularly for multivariable systems and also when more than one response is considered. Statistical design of experiments reduces the number of experiments to be performed, considers interactions among the variables and can be used for optimization of the operating parameters in multivariable systems. Response surface methodology (RSM) is used when only several significant factors are involved in optimization. Different types of RSM designs include 3-level factorial design, central composite design (CCD) [23]. Box- Behnken design [24] and Doptimal design [25].

A modified central composite experimental design known as the BoxBehnken design, is an independent, rotatable quadratic design with no embedded factorial or fractional factorial points where the variable combinations are at the midpoints of the edges of the variable space and at the center [26] Among all the RSM designs, Box-Behnken design requires fewer runs than the others, e.g, 15 runs for a 3-factor experimental design. By careful design and analysis of experiments, BoxBehnken design allows calculations of the response function at intermediate levels which were not experimentally studied and shows the direction if one wishes to change the input levels in order to decrease or increase the response [27].

\section{Material and Method 2.1. Chemicals}

High purity grade (99.5\%) of Triclosan $\left(\mathrm{C}_{12} \mathrm{H}_{7} \mathrm{C}_{13} \mathrm{O}_{2}\right)$, high purity grade $(99.5 \%)$ of 2,4-Dichlorophenol $\left(\mathrm{C}_{6} \mathrm{H}_{4} \mathrm{Cl}_{2} \mathrm{O}\right)$ and high purity grade (99.5\%) of 2,4,6Trichlorophenol $\quad\left(\mathrm{C}_{6} \mathrm{H}_{3} \mathrm{Cl}_{3} \mathrm{O}\right)$ were purchased from Dr. Ehrenstorfer $\mathrm{GmbH}$. These chemicals were used for obtaining calibration curve in HPLC device. Acetonitrile gradient grade for liquid chromatography $99.9 \% \quad\left(\mathrm{CH}_{3} \mathrm{CN}\right)$ was purchased from Merck and used to as HPLC solvents.

High purity grade (99\%) of Triclosan used for preparing stock solution in experiments was purchased from Alfa Aesar. Physico-chemical characteristics of Triclosan are summarized in Table 1. Methanol, 99.5\% $\quad\left(\mathrm{CH}_{3} \mathrm{OH}\right)$ purchased from Merck was used in order to dissolve Triclosan in stock solution.

Hydrogen peroxide solution (35\% w/w) obtained from Merck were used as an oxidant. Iron (II) sulfate heptahydrate, $98 \%\left(\mathrm{FeSO}_{4} \cdot 7 \mathrm{H}_{2} \mathrm{O}\right)$ used as source of $\mathrm{Fe}(\mathrm{II})$ in the photo-Fenton process, was analytical grade and purchased from Alfa Aesar Company. Concentrated stock solutions of Fe(II) (250 mg/L) were prepared for further dilution to obtain solutions of desired concentrations. Fe (II) stock solution was stored in dark to prevent oxidation of $\mathrm{Fe}(\mathrm{II})$. The $\mathrm{pH}$ of aqueous solutions was adjusted using either sodium hydroxide or sulfuric acid. All other chemicals were of analytical grade and used without any prior purification. Water for chemical solutions was purified using a Milli-Q system.

\subsection{Experimental procedure}

Photo-Fenton experiments were carried out at room temperature $\left(23 \pm 2^{\circ} \mathrm{C}\right)$ using different hydrogen peroxide and ferrous ion concentrations at $\mathrm{pH}$ of 3 which is 
suitable for photo-Fenton process [28]. For that reason, $\mathrm{pH}$ adjustment as 3 was applied with sulfuric acid solution addition in order to obtain $\mathrm{pH}$ value of the solution. Measurement of $\mathrm{pH}$ was done by using thermo scientific Orion $\mathrm{pH}$ meter 720a.

For a standard reaction run, $2 \mathrm{~L}$ of the synthetic wastewater sample was used. By preparation of synthetic wastewater, distilled water and triclosan stock solution was mixed to obtain determined concentration of triclosan which are 0.1 , 5.05 and $10 \mathrm{mg} / \mathrm{L}$. After pH adjustment, synthetic solution with desired concentration of triclosan was placed in the reactor and predetermined amounts of oxidant and catalyst were injected to the reactor at the beginning of each experiment. In batch experiments, Fe(II) (catalyst) was mixed well with synthetic wastewater before the addition of hydrogen peroxide (oxidant). The experiments were started by addition of $\mathrm{H}_{2} \mathrm{O}_{2}$ to the reactor. The UV lamp was immediately turned on. The time at which the ultraviolet lamp was turned on was considered as time zero or the beginning of the experiment. Samples withdrawn from the reactor at certain time intervals were analyzed immediately to avoid further reactions. Samples $(30 \mathrm{ml})$ of raw and treated triclosan solutions were withdrawn for analysis.

$\mathrm{pH}$ and conductivity levels were measured. Samples taken from the reactor were centrifuged on Hettich Universal $320 \mathrm{R}$ benchtop centrifuge before HPLC analyze in order to prevent clogging in column. Due to the fragility of the glass tubes, samples were centrifuged about 10 minutes at $3000 \mathrm{rpm}$. After the centrifuge application, samples were trasfered to HPLC samples tubes which were proper for using HPLC device.

\subsection{Experimental set-up}

\subsubsection{Configuration of UV Reactor}

Figure 2 depicts a schematic diagram of the laboratory-scale photochemical reactor used in UV oxidations. All batch photo-oxidation experiments were performed in the completely mixed, batch, cylindrical photochemical reactor with a total volume of $2.2 \mathrm{~L}$. The reactor is made of glass and does not contain any metal parts. The outside of the reactor was covered with an aluminum sheet for protection of human eyes to excessive UV radiation and to keep in the UV-light. The upper part of the reactor has inlets for feeding reactants, sample removals and ports for measuring temperature and withdrawing samples. The reactor was open to air and a Teflon-coated magnetic stirring bar was placed at the bottom of the reactor to provide a proper mixing. The reactor was placed on a magnetic stirrer (WiseStir MSH-20A).

The UV irradiation source was a $16 \mathrm{~W}$ low-pressure mercury vapor lamp (maximum emission at $254 \mathrm{~nm}$ ) placed in a quartz tube. The intensity of the UV radiation was measured using the ferrioxalate actinometry method and estimated to be $4.98^{*} 10^{-6}$ einstein $/ \mathrm{s}$ (mole of photons/second). Since the light source produces heat, the lamp was surrounded with a water-cooling jacket to conduct experiments at room or controlled temperatures; the lamp was axially centered and immersed in the reactor.

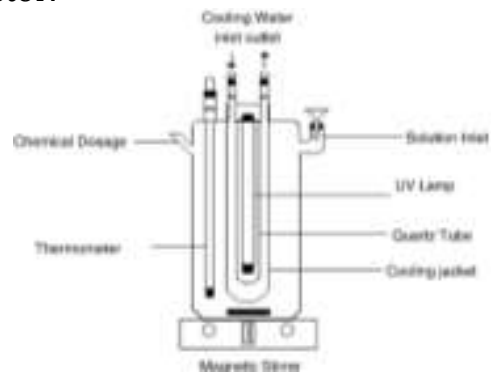

Figure 2. Schematic diagram of the lab-scale photochemical installation. 


\subsubsection{Analytical Methods}

Samples removed from UV reactor at pre-determined time intervals were centrifuged and then analyzed immediately for triclosan measurement. Triclosan, 2,4-Dichlorophenol (2,4-DCP) and 2,4,6-Trichlorophenol (2,4,6-TCP) concentrations of the samples was analyzed using an HPLC (Agilent 1100 model, USA) equipped with a UVdetector and a C18 column. The mobile phase composition was $\mathrm{H}_{2} \mathrm{O}$ /acetonitrile with a ratio $25 / 75$. The UV-detection was operated at $280 \mathrm{~nm}$. The flow rate was $1.5 \mathrm{~mL} \mathrm{~min}^{-1}$ and the injection volume was $20 \mu \mathrm{L}$. Under these conditions, the retention time for triclosan was $5 \mathrm{~min}$. The calibration curve for triclosan was constructed using the peak areas of the standard samples and were analyzed under the same conditions as that of the experimental samples. Stock solution of triclosan was prepared in 1 liter water and stored properly by protecting from the light. The calibration curve was prepared for concentrations between 10 $\mathrm{mg} / \mathrm{L}$ and $0.001 \mathrm{mg} / \mathrm{L}$ triclosan with a linearity of $\mathrm{R}^{2}=0.99997$.

The reaction times for 2,4-DCP and 2,4,6TCP were $1.680 \mathrm{~min}$. and $2.120 \mathrm{~min}$. respectively. The calibration curves were prepared for concentrations between 5 $\mathrm{mg} / \mathrm{L}$ and $0.001 \mathrm{mg} / \mathrm{L}$ for 2,4-DCP and $2,4,6$-TCP with a linearity of $\mathrm{R}^{2}=0.99996$ and 0.99993 .

\section{Results and Discussion}

Box Behnken statistical experiment design and the response surface methodology [29] was used to investigate the effects of the three independent variables on the response function and to determine the optimal conditions maximizing the percent removal of triclosan and minimize formation of by-products. The optimization procedure involves studying the response of the statistically designed combinations, estimating the coefficients by fitting the experimental data to the response function, predicting the response of the fitted model and checking the adequacy of the model. BoxBehnken statistical experiment design was used to evaluate the main effects, interaction effects, and quadratic effects of reaction conditions $\left(\mathrm{H}_{2} \mathrm{O}_{2}, \mathrm{Fe}\right.$ (II) and initial triclosan dose) on the triclosan removal. The independent variables were the dose of hydrogen peroxide $\left(\mathrm{X}_{1}\right)$, ferrous ion $\left(\mathrm{X}_{2}\right)$ and triclosan $\left(\mathrm{X}_{3}\right)$. The low, center and high levels of each variable are designated as $-1,0$, and +1 respectively as shown in Table 2 . The dependent variables were the triclosan removal $\left(\mathrm{Y}_{1}\right), 2,4$-DCP formation $\left(\mathrm{Y}_{2}\right)$, and 2,4,6-TCP formation $\left(\mathrm{Y}_{3}\right)$.

The initial concentration of triclosan $\left(\mathrm{X}_{3}\right)$ was ranged from 0.1 to $10 \mathrm{mg} / \mathrm{L}$. The highest concentrations of triclosan in river were reported as $5160 \mu \mathrm{g} / \mathrm{L}$ in India [12]. For that reason, range of triclosan doses in this study is acceptable for real conditions and surface waters. Although, triclosan is highly hydrophobic nature, high amount of its usage, triclosan concentrations increase in surface water and wastewater.

Table 2. Levels of variables in Box-Behnken Design

\begin{tabular}{|c|c|c|c|c|}
\hline $\begin{array}{l}\frac{0}{0} \\
\frac{\pi}{3} \\
\frac{\pi}{3} \\
>\end{array}$ & $\begin{array}{l}0 \\
\text { है } \\
\text { है }\end{array}$ & $\begin{array}{l}\underset{1}{7} \\
3 \\
0\end{array}$ & 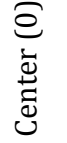 & 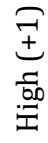 \\
\hline $\mathrm{H}_{2} \mathrm{O}_{2}(\mathrm{mM})$ & $\mathrm{X}_{1}$ & 1 & 25.5 & 50 \\
\hline $\mathrm{Fe}(\mathrm{II})(\mathrm{mM})$ & $\mathrm{X}_{2}$ & 0.1 & 2.55 & 5 \\
\hline Triclosan (mg/L) & $\mathrm{X}_{3}$ & 0.1 & 5.05 & 10 \\
\hline
\end{tabular}

The experimental conditions of the BoxBehnken experiment design for photoFenton oxidation are presented in Table 3. Observed and predicted results using Box-Behnken design are also presented in Table 4. 
E.Çokay and M.Öztamer / Degradation of Triclosan by Photo-Fenton Oxidation

Table 3. The experimental conditions of the Box-Behnken experiment design in photo-Fenton oxidation

\begin{tabular}{|c|c|c|c|c|c|c|}
\hline \multirow{2}{*}{$\begin{array}{c}\text { Run } \\
\text { No }\end{array}$} & \multicolumn{2}{|c|}{$\mathrm{X}_{1}, \mathrm{H}_{2} \mathrm{O}_{2}(\mathrm{mM})$} & \multicolumn{2}{|c|}{$\mathrm{X}_{2}, \mathrm{Fe}(\mathrm{II})(\mathrm{mM})$} & \multicolumn{2}{|c|}{$\mathrm{X}_{3}, \mathrm{TCS}(\mathrm{mg} / \mathrm{L})$} \\
\hline & Coded & Actual & Coded & Actual & Coded & Actual \\
\hline 1 & +1 & 50 & +1 & 5 & 0 & 5.05 \\
\hline 2 & +1 & 50 & -1 & 0.1 & 0 & 5.05 \\
\hline 3 & -1 & 1 & +1 & 5 & 0 & 5.05 \\
\hline 4 & -1 & 1 & -1 & 0.1 & 0 & 5.05 \\
\hline 5 & 0 & 25.5 & +1 & 5 & +1 & 10 \\
\hline 6 & 0 & 25.5 & +1 & 5 & -1 & 0.1 \\
\hline 7 & 0 & 25.5 & -1 & 0.1 & +1 & 10 \\
\hline 8 & 0 & 25.5 & -1 & 0.1 & -1 & 0.1 \\
\hline 9 & +1 & 50 & 0 & 2.55 & +1 & 10 \\
\hline 10 & +1 & 50 & 0 & 2.55 & -1 & 0.1 \\
\hline 11 & -1 & 1 & 0 & 2.55 & -1 & 0.1 \\
\hline 12 & -1 & 1 & 0 & 2.55 & +1 & 10 \\
\hline 13 & 0 & 25.5 & 0 & 2.55 & 0 & 5.05 \\
\hline 14 & 0 & 25.5 & 0 & 2.55 & 0 & 5.05 \\
\hline 15 & 0 & 25.5 & 0 & 2.55 & 0 & 5.05 \\
\hline
\end{tabular}

Table 4. Observed and predicted results for the response functions for photo-Fenton Oxidation

\begin{tabular}{|c|c|c|c|c|c|c|}
\hline \multirow[b]{2}{*}{$\begin{array}{l}\text { Run } \\
\text { No }\end{array}$} & \multicolumn{3}{|c|}{ Predicted Results } & \multicolumn{3}{|c|}{ Observed Results } \\
\hline & $\begin{array}{c}\mathrm{Y}_{1}, \mathrm{TCS} \\
\text { removal } \\
(\%) \\
\end{array}$ & $\begin{array}{c}\mathrm{Y}_{2,}, 2,4-\mathrm{DCP} \\
\text { formation } \\
(\mathrm{mg} / \mathrm{L})\end{array}$ & $\begin{array}{c}\mathrm{Y}_{3}, 2,4,6-\mathrm{TCP} \\
\text { formation } \\
(\mathrm{mg} / \mathrm{L})\end{array}$ & $\begin{array}{c}\mathrm{Y}_{1}, \mathrm{TCS} \\
\text { removal } \\
(\%) \\
\end{array}$ & $\begin{array}{c}\mathrm{Y}_{2}, 2,4-\mathrm{DCP} \\
\text { formation } \\
(\mathrm{mg} / \mathrm{L})\end{array}$ & $\begin{array}{c}\mathrm{Y}_{3}, 2,4,6-\mathrm{TCP} \\
\text { formation } \\
(\mathrm{mg} / \mathrm{L})\end{array}$ \\
\hline 1 & 87.45 & 0.95 & 0.05 & 86.58 & 0.96 & 0.06 \\
\hline 2 & 99.70 & 0.63 & 0.12 & 97.55 & 0.49 & 0.06 \\
\hline 3 & 65.85 & 1.02 & 0.61 & 68.00 & 1.16 & 0.67 \\
\hline 4 & 79.93 & 0.96 & 0.93 & 80.80 & 0.96 & 0.91 \\
\hline 5 & 2.05 & 0.24 & 0.23 & 7.00 & 0.15 & 0.10 \\
\hline 6 & 81.22 & 0.11 & 0.00 & 75.00 & 0.05 & 0.00 \\
\hline 7 & 69.66 & 0.00 & 0.68 & 75.88 & 0.05 & 0.62 \\
\hline 8 & 39.95 & 0.00 & 0.00 & 35.00 & 0.06 & 0.00 \\
\hline 9 & 83.88 & 1.01 & 0.00 & 79.80 & 1.09 & 0.09 \\
\hline 10 & 92.51 & 0.94 & 0.07 & 99.60 & 0.98 & 0.00 \\
\hline 11 & 87.92 & 1.13 & 0.12 & 92.00 & 1.05 & 0.00 \\
\hline 12 & 47.09 & 1.22 & 1.31 & 40.00 & 1.18 & 1.38 \\
\hline 13 & 82.04 & 0.82 & 0.09 & 82.06 & 0.82 & 0.09 \\
\hline 14 & 82.04 & 0.82 & 0.09 & 82.00 & 0.83 & 0.09 \\
\hline 15 & 82.04 & 0.82 & 0.09 & 82.06 & 0.82 & 0.09 \\
\hline
\end{tabular}

\subsection{The regression model}

The application of RSM offers an empirical relationship between the response function and the independent variables. The mathematical relationship between the response function (Y) and the independent variables (X) can be approximated by a quadratic (secondorder) polynomial equation as follows:

$\mathrm{Y}=\mathrm{b}_{0}+\mathrm{b}_{1} \mathrm{X}_{1}+\mathrm{b}_{2} \mathrm{X}_{2}+\mathrm{b}_{3} \mathrm{X}_{3}+\mathrm{b}_{12} \mathrm{X}_{1} \mathrm{X}_{2}+$ $b_{13} X_{1} X_{3}+b_{23} X_{2} X_{3}+b_{11} X_{1}^{2}+b_{22} X_{2}^{2}+b_{33} X_{3}^{2}$ (1)

This approach was selected as relatively fewer combinations of the variables were chosen to estimate a potential complex response function. A total of 15 experiments are needed to calculate 9 coefficients of the second-order polynomial regression model. This model contains one block term, three linear terms, three quadratic terms, and three interaction terms. The coefficients of the response functions for different dependent variables were determined correlating the experimental results with the relevant functions used in a Stat-Ease regression program. Different response functions with the determined coefficients are presented by Eqs. (2) to (4). 
The results of analysis of variance (ANOVA) are also presented in Tables 57 indicating the fact that that the predictability of the model is at $95 \%$ confidence interval. Response function predictions are in good agreement with the experimental data with a coefficient of determination $\left(\mathrm{R}^{2}\right)$ of larger than 0.99 . Furthermore, the computed $F$ value is much greater than that of the tabular $\mathrm{F}_{0.01}(14,14)$ value of 3.70 suggesting that the treatment is highly significant. $P$ values of less than 0.05 for any factor in analysis of variance (ANOVA) indicated a $\mathrm{Y}_{1}=51.77202-1.24196 \mathrm{X}_{1}+20.53498 \mathrm{X}_{2}+9.61251 \mathrm{X}_{3}+7.62182 \times 10^{-3} \mathrm{X}_{1} \mathrm{X}_{2}+0.066378 \mathrm{X}_{1} \mathrm{X}_{3}-$ $2.24449 \mathrm{X}_{2} \mathrm{X}_{3}+0.025675 \mathrm{X}_{1}^{2}-2.36880 \mathrm{X}_{2}^{2}-0.79997 \mathrm{X}_{3}^{2}\left(\mathrm{R}^{2}=0.9703\right)$

$\mathrm{Y}_{2}=0.66504-0.052059 \mathrm{X}_{1}+0.39233 \mathrm{X}_{2}+0.11901 \mathrm{X}_{3}+1.10561 \times 10^{-3} \mathrm{X}_{1} \mathrm{X}_{2}-3.70831 \times 10^{-5} \mathrm{X}_{1} \mathrm{X}_{3}+$ $2.13523 \times 10^{-3} \mathrm{X}_{2} \mathrm{X}_{3}+8.87897 \times 10^{-4} \mathrm{X}_{1}^{2}-0.076930 \mathrm{X}_{2}^{2}-0.011388 \mathrm{X}_{3}^{2}\left(\mathrm{R}^{2}=0.9694\right)$

$\mathrm{Y}_{3}=0.23199-0.025393 \mathrm{X}_{1}-0.071478 \mathrm{X}_{2}+0.14479 \mathrm{X}_{3}+1.00857 \times 10^{-3} \mathrm{X}_{1} \mathrm{X}_{2}-2.65269 \times 10^{-3} \mathrm{X}_{1} \mathrm{X}_{3}$ $-0.010885 \mathrm{X}_{2} \mathrm{X}_{3}+4.34228 \times 10^{-4} \mathrm{X}_{1}^{2}+0.012059 \mathrm{X}_{2}^{2}+5.84157 \mathrm{X}_{2}^{2}\left(\mathrm{R}^{2}=0.9654\right)$

Table 5. ANOVA test for response function $\mathrm{Y}_{1}$ (\% TCS removal)

\begin{tabular}{|c|c|c|c|c|c|}
\hline Source & Sum of squares & d.f. & Mean square & F Value & p-value \\
\hline Model & 8854.13 & 9 & 983.79 & 18.15 & 0.0026 \\
\hline $\mathrm{X}_{1}-\mathrm{H}_{2} \mathrm{O}_{2}$ & 855.53 & 1 & 855.53 & 15.78 & 0.0106 \\
\hline $\mathrm{X}_{2}-\mathrm{Fe}^{+2}$ & 346.5 & 1 & 346.5 & 6.39 & 0.0526 \\
\hline $\mathrm{X}_{3}-\mathrm{TCS}$ & 1223.15 & 1 & 1223.15 & 22.57 & 0.0051 \\
\hline $\mathrm{X}_{1} \mathrm{X}_{2}$ & 0.84 & 1 & 0.84 & 0.015 & 0.9059 \\
\hline $\mathrm{X}_{1} \mathrm{X}_{3}$ & 259.21 & 1 & 259.21 & 4.78 & 0.0804 \\
\hline $\mathrm{X}_{2} \mathrm{X}_{3}$ & 2963.71 & 1 & 2963.71 & 54.68 & 0.0007 \\
\hline $\mathrm{X}_{1}{ }^{2}$ & 876.95 & 1 & 876.95 & 16.18 & 0.0101 \\
\hline $\mathrm{X}_{2}^{2}$ & 746.48 & 1 & 746.48 & 13.77 & 0.0138 \\
\hline $\mathrm{X}_{3}{ }^{2}$ & 1418.62 & 1 & 1418.62 & 26.17 & 0.0037 \\
\hline Residual & 271.01 & 5 & 54.2 & & \\
\hline Lack of Fit & 271.01 & 3 & 90.34 & 75281.23 & $<0.0001$ \\
\hline Pure Error & $2.40 \times 10^{-3}$ & 2 & $1.20 \times 10^{-3}$ & & \\
\hline Total (Corr) & 9125.14 & 14 & & & \\
\hline
\end{tabular}

Table 6. ANOVA test for the response function $\mathrm{Y}_{2}$ (\% 2,4-DCP Formation)

\begin{tabular}{cccccc}
\hline Source & Sum of squares & d.f. & Mean square & F Value & p-value \\
\hline Model & 2.48 & 9 & 0.28 & 17.59 & 0.0028 \\
$\mathrm{X}_{1}-\mathrm{H}_{2} \mathrm{O}_{2}$ & 0.082 & 1 & 0.082 & 5.27 & 0.0702 \\
$\mathrm{X}_{2}-\mathrm{Fe}^{+2}$ & 0.073 & 1 & 0.073 & 4.66 & 0.0834 \\
$\mathrm{X}_{3}-\mathrm{TCS}$ & 0.014 & 1 & 0.014 & 0.90 & 0.3856 \\
$\mathrm{X}_{1} \mathrm{X}_{2}$ & 0.018 & 1 & 0.018 & 1.13 & 0.3374 \\
$\mathrm{X}_{1} \mathrm{X}_{3}$ & $8.090 \times 10^{-5}$ & 1 & $8.090 \times 10^{-5}$ & $5.166 \times 10^{-3}$ & 0.9455 \\
$\mathrm{X}_{2} \mathrm{X}_{3}$ & $2.682 \times 10^{-3}$ & 1 & $2.682 \times 10^{-3}$ & 0.17 & 0.6961 \\
$\mathrm{X}_{1}{ }^{2}$ & 1.05 & 1 & 1.05 & 66.98 & 0.0004 \\
$\mathrm{X}_{2}{ }^{2}$ & 0.79 & 1 & 0.79 & 50.28 & 0.0009 \\
$\mathrm{X}_{3}{ }^{2}$ & 0.29 & 1 & 0.29 & 18.36 & 0.0078 \\
Residual & 0.078 & 5 & 0.016 & & 0.0008 \\
Lack of Fit & 0.078 & 3 & 0.026 & 1298.20 & 0.000 \\
Pure Error & $4.019 \times 10^{-5}$ & 2 & $2.009 \times 10^{-5}$ & & \\
Total (Corr) & 2.56 & 14 & & &
\end{tabular}

R-squared $=0.9694$, R-squared (adjusted for $\mathrm{df}$ ) $=0.9143$, standard error of estimate $=0,13$ 
Table 7. ANOVA test for the response function $\mathrm{Y}_{3}(2,4,6$-TCP Formation)

\begin{tabular}{cccccc}
\hline Source & Sum of squares & d.f. & Mean square & F Value & p-value \\
\hline Model & 2.38 & 9 & 0.26 & 15.50 & 0.0038 \\
$\mathrm{X}_{1}-\mathrm{H}_{2} \mathrm{O}_{2}$ & 0.95 & 1 & 0.95 & 55.64 & 0.0007 \\
$\mathrm{X}_{2}-\mathrm{Fe}^{+2}$ & 0.074 & 1 & 0.074 & 4.32 & 0.0921 \\
$\mathrm{X}_{3}-\mathrm{TCS}$ & 0.60 & 1 & 0.60 & 35.06 & 0.0020 \\
$\mathrm{X}_{1} \mathrm{X}_{2}$ & 0.015 & 1 & 0.015 & 0.86 & 0.3969 \\
$\mathrm{X}_{1} \mathrm{X}_{3}$ & 0.41 & 1 & 0.41 & 24.22 & 0.0044 \\
$\mathrm{X}_{2} \mathrm{X}_{3}$ & 0.070 & 1 & 0.070 & 4.08 & 0.0994 \\
$\mathrm{X}_{1}{ }^{2}$ & 0.25 & 1 & 0.25 & 14.68 & 0.0122 \\
$\mathrm{X}_{2}{ }^{2}$ & 0.019 & 1 & 0.019 & 1.13 & 0.3360 \\
$\mathrm{X}_{3}{ }_{\text {Residual }}$ & $7.564 \times 10^{-4}$ & 1 & $7.564 \times 10^{-4}$ & 0.044 & 0.8417 \\
Lack of Fit & 0.085 & 5 & 0.017 & & $<0.0001$ \\
Pure Error & 0.085 & 3 & 0.028 & & \\
Total (Corr) & $3.564 \times 10^{-8}$ & 2 & $1.782 \times 10^{-8}$ & & \\
\hline R-squared = 0.9654, R-squared (adjusted for df) $=0.9031$, standard error of estimate $=0,13$ &
\end{tabular}

\subsection{Removal of Triclosan}

Response functions with determined coefficients were used to estimate variations of response functions with the independent variables under different conditions. Figure 3 shows the effect of initial Fe(II) concentration on percent triclosan removal at different
$\mathrm{H}_{2} \mathrm{O}_{2}$ concentrations after $60 \mathrm{~min}$ of reaction time when initial concentration of triclosan was $0.1 \mathrm{mg} / \mathrm{L}$. As expected, percent triclosan removal increased with increasing initial hydrogen peroxide at low triclosan concentrations such as $0.1 \quad \mathrm{mg} / \mathrm{L}$.

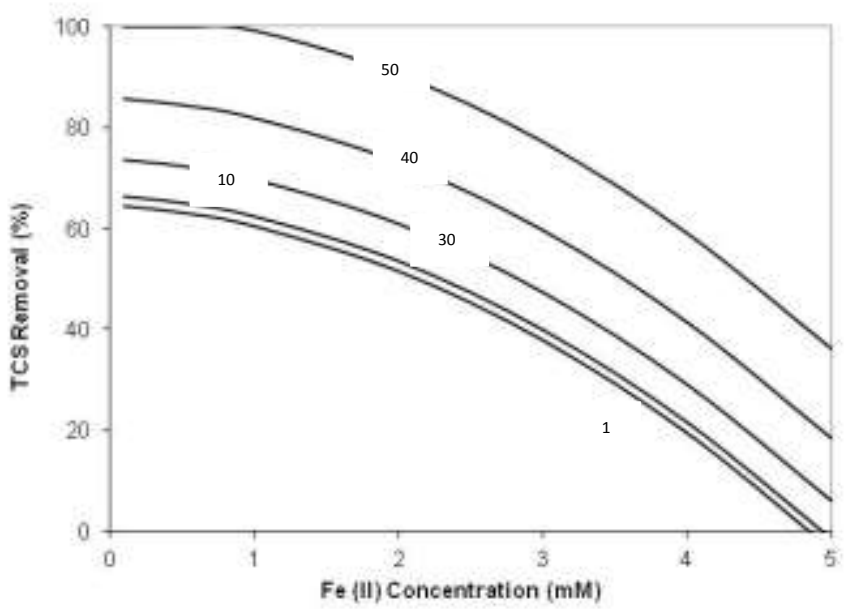

Figure 3. Variation of percent triclosan removals with Fe (II) concentrations at different initial $\mathrm{H}_{2} \mathrm{O}_{2}$ concentration at initial concentration of triclosan was $0.1 \mathrm{mg} / \mathrm{L}$.

Percent triclosan removals were 92 and 99.6\% when $\mathrm{H}_{2} \mathrm{O}_{2}$ concentrations of 1 and $50 \mathrm{mM}$, respectively, at an initial triclosan concentration of $0.1 \mathrm{mg} / \mathrm{L}$ and at a Fe (II) concentration of $2 \mathrm{mM}$. In addition to this, complete degradation was realized at $\mathrm{H}_{2} \mathrm{O}_{2}$ concentration of 50
$\mathrm{mM}$ and Fe (II) concentrations above 5 $\mathrm{mM}$ after 60 min reaction time. Percent triclosan removals were 75 and $35 \%$ when a Fe (II) concentrations of 5 and $0.1 \mathrm{mM}$, respectively, at a $\mathrm{H}_{2} \mathrm{O}_{2}$ concentrations of $25 \mathrm{mM}$ and initial triclosan concentration of $0.1 \mathrm{mg} / \mathrm{L}$. 
These results are in agreement with the literature reports, where a beneficial effect of increasing Fe (II) was observed in photo-degradation of pesticides [30]. Percent triclosan removal increased with increasing initial hydrogen peroxide concentration at all initial triclosan concentrations. However, this phenomenon is not viable for using high ferrous ion levels at all initial triclosan concentrations. As can be seen in Figure 4 , percent triclosan removals were 40 , 75.88 and $79.80 \%$ when $\mathrm{H}_{2} \mathrm{O}_{2}$ concentrations of 1,25 and $50 \mathrm{mM}$, respectively at a $\mathrm{Fe}(\mathrm{II})$ concentration of $0.1 \mathrm{mM}$ and at an initial triclosan concentration of $10 \mathrm{mg} / \mathrm{L}$.

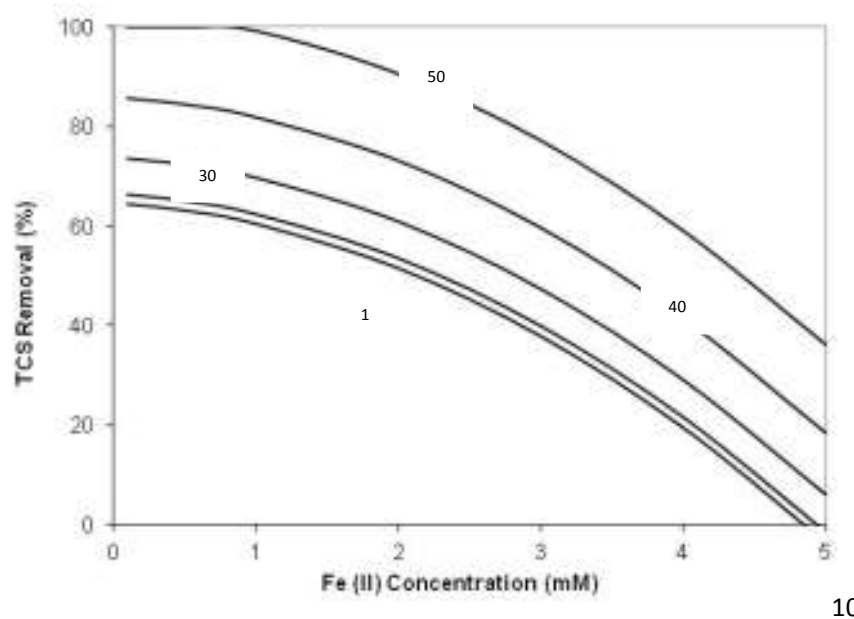

Figure 4. Variation of percent triclosan removals with Fe (II) concentrations at unferent initial $\mathrm{H}_{2} \mathrm{O}_{2}$ concentration at initial concentration of triclosan was $10 \mathrm{mg} / \mathrm{L}$.

When ferrous ion increased to $5 \mathrm{mM}$, percent triclosan removals were 0,10 and $45 \%$ when $\mathrm{H}_{2} \mathrm{O}_{2}$ concentrations of 1 , 25 and $50 \mathrm{mM}$, respectively. It can be said that complete degradation was realized at $\mathrm{H}_{2} \mathrm{O}_{2}$ concentration of $50 \mathrm{mM}$ and $\mathrm{Fe}(\mathrm{II})$ concentrations below $1 \mathrm{mM}$ after 60 min reaction time while higher concentrations of Fe(II) did not result in complete triclosan degradation. Because, high iron concentrations can also scavenge $\mathrm{OH}^{\bullet}$ yielding lower levels of oxidation. Apparently the use of high catalyst concentrations inhibited the removal of color due to formation of radical scavengers. Moreover, there is a need for strict $\mathrm{pH}$ control to avoid precipitation of iron hydroxides which can prevent penetration of light due to high turbidity or optical density of the solution slowing down the generation of Fe(II) and consequently the degradation reaction. As a result of these evaluations, at low triclosan concentration of $0.1 \mathrm{mg} / \mathrm{L}$, the optimal $\mathrm{H}_{2} \mathrm{O}_{2} / \mathrm{Fe}(\mathrm{II}) /$ triclosan concentration yielding the highest triclosan removal (99.60\%) was 50/2/0.1, while at a high triclosan concentration of $10 \mathrm{mg} / \mathrm{L}$ this ratio was $50 / 2 / 10$ yielding $79.80 \%$ triclosan removal. The ANOVA analysis was also indicated that all three variables triclosan, $\mathrm{H}_{2} \mathrm{O}_{2}$ and $\mathrm{Fe}(\mathrm{II})$ concentrations and the interactions $\left(\mathrm{X}_{1}\right.$, $\mathrm{X}_{3}, \mathrm{X}_{2} \mathrm{X}_{3}, \mathrm{X}_{1}^{2}, \mathrm{X}_{2}^{2}$ and $\mathrm{X}_{3}{ }^{2}$ ) were significant and played important roles in degradation of triclosan by the photoFenton oxidation as summarized in Table 5 .

Photo-Fenton treatment more effective at high $\mathrm{H}_{2} \mathrm{O}_{2}$ concentration but high initial $\mathrm{H}_{2} \mathrm{O}_{2}$ concentration also results high amount of by-products formation as shown in Figure 5. Higher initial triclosan concentrations required higher 
amounts of the $\mathrm{H}_{2} \mathrm{O}_{2}$ concentrations for complete degradation. At this situation, formation of the highly toxic byproducts was the critic limitation factor of the degradation. Formation of the byproducts which are named as 2,4-DCP $\left(\mathrm{Y}_{2}\right)$ increases with the $\mathrm{Fe}(\mathrm{II})$ concentration $\left(\mathrm{X}_{2}\right)$, the $\mathrm{H}_{2} \mathrm{O}_{2}$ concentration $\left(\mathrm{X}_{1}\right)$. This situation is not good for oxidation processes. In addition to this, $\mathrm{Fe}(\mathrm{II})$ concentration $\left(\mathrm{X}_{2}\right)$ has a more profound negative effect by the formation of 2,4-DCP $\left(\mathrm{Y}_{2}\right)$. So, it can be said that high concentration of oxidant and catalyst are not suitable for optimum reaction conditions to mineralize triclosan.

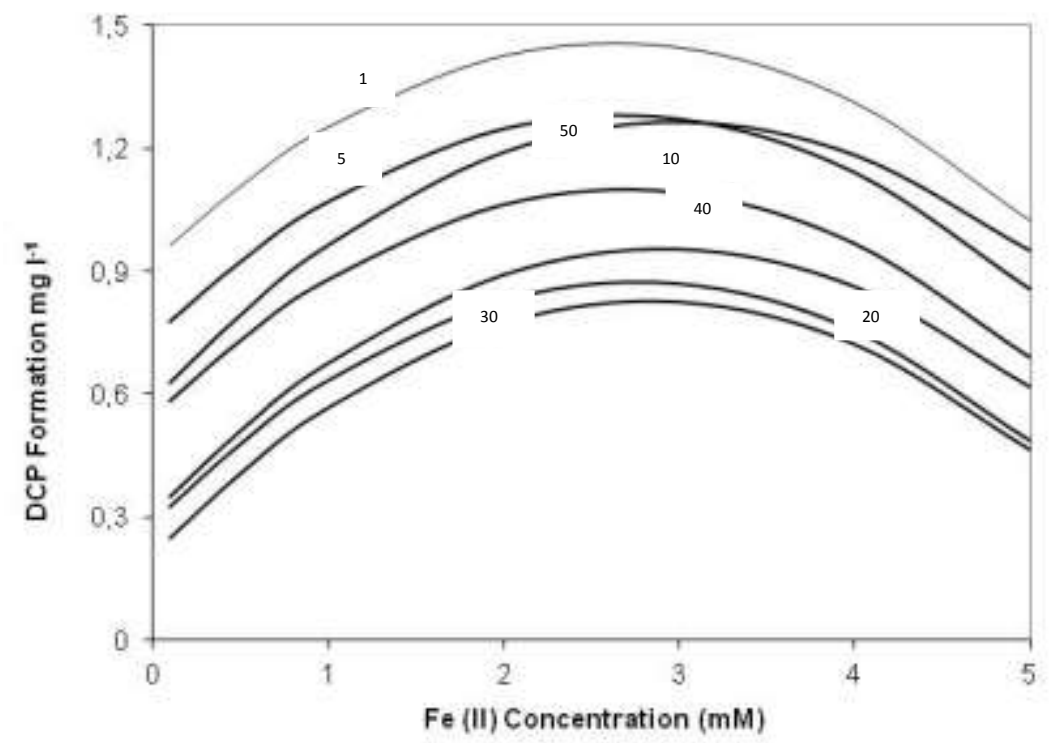

Figure 5. Variation of 2,4-DCP Formation with Fe (II) concentrations with different initial $\mathrm{H}_{2} \mathrm{O}_{2}$ concentrations at initial concentration of $5 \mathrm{mg} / \mathrm{L}$ triclosan.

As a result of these evaluations, at low triclosan concentration of $0.1 \mathrm{mg} / \mathrm{L}$, the optimal $\quad \mathrm{H}_{2} \mathrm{O}_{2} / \mathrm{Fe}(\mathrm{II}) /$ triclosan concentration yielding the lowest DCP formation $\left(0.002 \quad \mathrm{mgl}^{-1}\right) \quad$ was 27.5/0.2/0.1, while at a high triclosan concentration of $10 \mathrm{mg} / \mathrm{L}$ this ratio was 27.8/0.15/10 yielding $0.045 \mathrm{mg} \mathrm{l}^{-1}$ DCP formation. The ANOVA analysis has shown that all three variables triclosan, $\mathrm{H}_{2} \mathrm{O}_{2}$ and $\mathrm{Fe}(\mathrm{II})$ concentrations $\left(\mathrm{X}_{1}{ }^{2}, \mathrm{X}_{2}{ }^{2}\right.$ and $\mathrm{X}_{3}{ }^{2}$ ) were significant and played important roles in formation of byproducts by the photo-Fenton oxidation as summarized in Table 6.

According to TCP formation, it can be said that formation of the byproduct named as 2,4,6-TCP decreases with $\mathrm{H}_{2} \mathrm{O}_{2}$ concentration but increases with Fe(II) concentration.

As a result of these evaluations, at low triclosan concentration of $0.1 \mathrm{mg} / \mathrm{L}$, the optimal $\quad \mathrm{H}_{2} \mathrm{O}_{2} / \mathrm{Fe}(\mathrm{II}) /$ triclosan concentration yielding the lowest TCP formation $\left(0.00 \mathrm{mg} \mathrm{l}^{-1}\right)$ was 25/0.1/0.1, while at a high triclosan concentration of $10 \mathrm{mg} / \mathrm{L}$ this ratio was 50/5/10 yielding $\left(0.00 \mathrm{mg} \mathrm{l}^{-1}\right)$ the lowest TCP formation. The ANOVA analysis has demonstrated that all three variables $\mathrm{H}_{2} \mathrm{O}_{2}$ and triclosan concentrations and the interactions $\left(\mathrm{X}_{1}, \mathrm{X}_{3}, \mathrm{X}_{1} \mathrm{X}_{3}\right.$ and $\left.\mathrm{X}_{1}^{2}\right)$ were significant and played important roles in formation of by-products by the photo-Fenton oxidation as summarized in Table 7. 


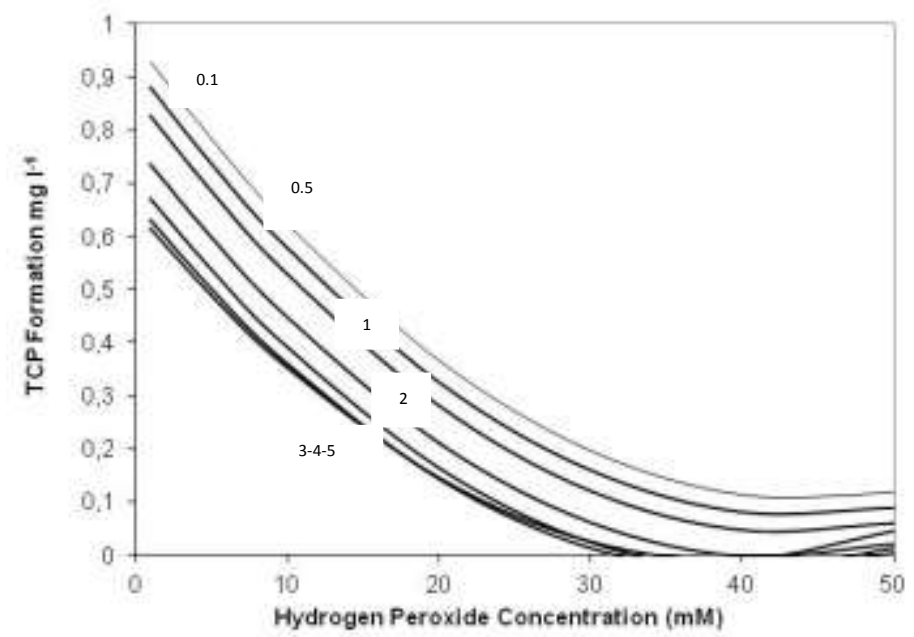

Figure 6. Variation of 2,4,6-TCP Formation with $\mathrm{H}_{2} \mathrm{O}_{2}$ concentrations with different $\mathrm{Fe}$ (II) concentration at initial concentration of $5 \mathrm{mg} / \mathrm{L}$ triclosan.

\section{Discussion and Conclusion}

Triclosan degradation by photo-Fenton oxidation was investigated over a large range of reactant concentrations. BoxBehnken statistical experiment design and the response surface methodology (RSM) were used for this purpose. Experimental data was used to determine the coefficients of the response functions. Predictions obtained from the response functions were in good agreement with the experimental results indicating the reliability of the method used. In photo-Fenton treatment, the optimum conditions were based on initial triclosan concentrations. Lower initial triclosan concentrations required lower amounts of the $\mathrm{H}_{2} \mathrm{O}_{2}$ concentrations and $\mathrm{Fe}(\mathrm{II})$ concentrations while higher initial triclosan concentrations required higher amounts of oxidant and catalyst for complete degradation. The $\mathrm{H}_{2} \mathrm{O}_{2}$ concentration has a more profound effect on percent removal of triclosan as compared to $\mathrm{Fe}(\mathrm{II})$ concentrations in photo-Fenton process. In this context, high initial $\mathrm{H}_{2} \mathrm{O}_{2}$ concentration results high formation of by-products such as 2,4-DCP and 2,4,6TCP. This situation is not good for oxidation processes. Based on this, it can be concluded that high concentration of oxidant and catalyst is not suitable for optimum reaction conditions. After these evaluations, the highest triclosan removal $(99.5 \%)$ was obtained with a $\mathrm{H}_{2} \mathrm{O}_{2} / \mathrm{Fe}(\mathrm{II}) /$ triclosan ratio of 50/0.1/10. At these reaction conditions, 2,4-DCP and 2,4,6-TCP were observed as $0.297 \mathrm{mgl}^{-1}$ and $0.232 \mathrm{mg} \mathrm{l}^{-1}$, respectively, in photoFenton treatment. As a conlusion, photoFenton process can be used for the removal of triclosan and by-products, at real conditions.

\section{References}

[1] Bedoux, G., Roig, B., Thomas, O., Dupont, V., Le Bot, B. 2012. Occurrence and toxicity of antimicrobial triclosan and byproducts in the environment, Environ Science Pollution Res. Vol.19, page.1044-1065.

[2] Reiss, R., Mackay, N., Habig, C., Griffin, J. 2002. An ecological risk assessment for triclosan in lotic systems following discharge from wastewater treatment plants in the United States, Environmental Toxicology and Chemistry, Vol.21, page.2483-2492. 
[3] NICNAS (Chemicals Notification and Assessment Scheme), Priority Existing Chemical Assessment Report No. National Industrial 30 Triclosan, Australia, 2009.

[4] Scientific Committee on Consumfin 1] Lindström, A., Buerge, I. J., Poiger, T., Products (SCCP), Opinion on: Triclosan Retrieved from http://ec.europa.eu/health/ph_risk/com mittees/04_sccp/docs/sccp_o_166.pdf on October, 022015.

[5] Perez, A.L., De Sylor., M.A. Slocombe, A.J. Lew, M.G. 2013. Triclosan occurrence in freshwater systems in the united states (1999-2012): a meta analysis, [12]. Ramaswamy, B. R., Shanmugam,

Environmental Toxicology and G., Velu, G., Rengarajan, B. \& Chemistry, Vol.32 (7), page.1479-1487

[6] Singer, H., Muller, S., Tixier, C., Pillonel, L. 2002. Triclosan: occurrence and fate of a widely used biocide in the aquatic environment: Field measurements in wastewater treatment plants, surface waters, and lake sediments, Environmental Science and Technology, Vol.36, page. 4998-5004.

[7] Halden, R. U., Paul, D. H. 2005. Cooccurrence of triclocarban and triclosan in U.S. water resources, Environmental Science and Technology, Vol.39, page. 1420-1426.

[8] Peng, X., Yu, Y., Tang, C., Tan, J., Huang, Q., Wang, Z. 2008. Occurrence of steroid estrogens, endocrine-disrupting phenols and acid pharmaceutical residues in urban riverine water of the Pearl River Delta, South China, Science of Total Environment, Vol.397, page. 158-166.

[9] Zhao, J. L., Ying, G. G., Liu, Y. S., Chen, F., Yang, J. F., Wang, L. 2010. Occurrence and risks of triclosan and triclocarban in the Pearl River system, South China: From source to the receiving environment, Journal of Hazardous Material, Vol.179, page. 215-222.

[10] Bedoux, G., Roig, B., Thomas, O., Dupont, V. Le Bot, B. 2012.
Occurrence and toxicity of antimicrobial triclosan and byproducts in the environment, Environmental Science Pollution Research, Vol.19, page.1044-1065. Bergqvist, P. A., Müller, M. D., Buser, H. R. 2002. Occurrence and environmental behavior of the bactericide triclosan and its methyl derivative in surface waters and in wastewater, Environmental Science and Technology, Vol.36, page. 2322 2329. Larsson, D. G. J. (2011). GC-MS analysis and ecotoxicological risk assessment of triclosan, carbamazepine and parabens in Indian rivers, Journal of Hazardous Materials, Vol.186, page.1586-1593.

[13] Tixier, C., Singer, H. P., Canonica, S., Stephan, R. 2002. Phototransformation of triclosan in surface waters: A relevant elimination process for this widely used biocide laboratory studies, field measurements, and modeling, Environmental Science and Technology, Vol.36, page.34823489.

14]Sanchez-Prado, L., Llompart, M., Lores, M., Fernández-Alvarez, M., García-Jares, C., Cela, R. 2006. Further research on photo-SPME of triclosan, Analytical and Bioanalytical Chemistry, Vol.384, page.1548-1457.

[15] Canosa, P., Morales, S., Rodríguez, I., Rubí, E., Cela, R., Gómez M. 2005. Aquatic degradation of triclosan and formation of toxic chlorophenols in presence of low concentrations of free chlorine, Analytical and Bioanalytical Chemistry, Vol.383, page.1119-1126. 
[16] Latch, D.E., Packer, J.L., Arnold, W.A., McNeill, K. 2003. Photochemical conversion of triclosan to 2,8dichlorodibenzo-p-dioxin in aqueous solution, Journal of Photochemistry and Photobiology A: Chemistry, Short Communication, Vol.158, page.630666.

[17] Ferrer, I. Mezcua, M. Jose Gomez, M., Thurman, M.E., Aguera, A., Hernando, M.D., Fernandez-alba, A.R. 2004. Liquid chromatography/time-of-flight mass spectrometric analyses for the elucidation of the photodegredation products of triclosan in wastewater samples, Rapid Communications in Mass Spectrometry, Vol.18, page.443450.

[18] Esplugas, S., Yue, P.L., Pervez, M.I. 1994. Degradation of 4-chlorophenol by photolytic oxidation, Water Research, Vol.28 (6), page.1323-1328.

[19] Masten, S.J., Davies, S.H.R. 1994. The use of ozonation to degrade organic contaminants in wastewaters, Env.Sci.Technol. Vol.28 (1), page.180A-185A.

[20] Buxton, G.V., Greenstock, C.L., Helman, W.P., Ross, A.B. 1988. Critical review of data constants for reactions of hydrated electrons, hydrogen atoms and hydroxyl[28 radicals in aqueous solutions, J. Phys. Chem. Ref. Data, Vol.17(2), page.513-586.

[21] Legrini, O., Oliveros, E., Braun, A.M. 1993. Photochemical processes for water treatment, Chem. Rew. Vol.93 (2), page.671-698.

[22] Rule, K.L., Ebbett, V.R., Vikesland, P.J. 2005. Formation of chloroform and chlorinated organics by freechlorine-mediated oxidation of triclosan, Environ. Sci. Technol. Vol.39, page. 3176-3185.

[23] Boza, A., De la Cruz, Y., Jordan, G., Jauregui-Haza, U., Aleman, A., Caraballo, I. 2000. Statistical optimization of a sustained-release matrix tablet of lobenzarit disodium, Drug Dev Ind Pharm. Vol.26, page.1303-1307.

[24] Singh, S.K., Dodge, J., Durrani, M.J., Khan, M.A. 1995. Optimization and characterization of controlled release pellets coated with experimental latex: I. Anionic drug, Int J Pharm. Vol.125, page.243-255.

[25] Sanchez-Lafuente, C., Furlanetto, S., Fernandez-Arevalo, M. 2002. Didanosine extended-release matrix tablets: optimization of formulation variables using statistical experimental design, Int J Pharm. Vol.237, page.107-118.

[26] Ragonese, R., Macka, M., Hughes, J., Petocz, P. 2002. The use of the BoxBehnken experimental design in the optimisation and robustness testing of a capillary electrophoresis method for the analysis of ethambutol hydrochloride in a pharmaceutical formulation, J Pharm Biomed Anal. Vol.27, page.995-1007.

[27] Hamed, E., Sakr, A. 2001. Application of multiple response optimization technique to extended release formulations design, J Control Release, Vol.73, page.329-338.

28] Hsueh, C.L., Huang, Y.H., Wang, C.C., Chen, C.Y. 2005. Degradation of azo dyes using low iron concentration of Fenton and Fenton-like system, Chemosphere, Vol.58, page.14091414.

[29] Charles, R.H., Kennneth, Jr V.T. 1999. Fundamental concepts in the design of experiments, Oxford: University Press.

[30] Torrades, F., Perez, M., Mansilla, H.D., Peral, J. 2003. Experimental design of Fenton and photo-Fenton reactions for the treatment of cellulose bleaching effluents, Chemosphere, Vol.53 (10), page.1211-1220. 